\title{
A Dual Electrochemical Sensor Based on a Test-strip Assay for the Quantitative Determination of Albumin and Creatinine
}

\author{
Tomoyuki Yasukawa, ${ }^{\dagger}$ Yuya Kiba, and Fumio Mizutani \\ University of Hyogo, 3-2-1 Kouto, Kamigori, Ako, Hyogo 678-1297, Japan
}

\begin{abstract}
A dual-electrochemical sensor based on a test-strip assay with immunochemistry and enzyme reactions has been developed for the determination of albumin and creatinine. Each nitrocellulose membrane with an immobilization area of an anti-albumin antibody or three enzymes was prepared in the device with three working electrodes for measuring albumin, creatinine, and ascorbic acid, as well as an $\mathrm{Ag} / \mathrm{AgCl}$ electrode used as a counter/pseudo-reference electrode. The reactions of three enzymes were initiated by flowing a solution containing creatinine to detect an oxidation current of hydrogen peroxide. A sandwich-type immunocomplex was formed by albumin and antibody labeled with glucose oxidase (GOx). Captured GOx catalyzed the reduction of $\mathrm{Fe}(\mathrm{CN})_{6}{ }^{3-}$ to $\mathrm{Fe}(\mathrm{CN})_{6}{ }^{4-}$, which was oxidized electrochemically to determine the captured albumin. The responses for creatinine and albumin increased with the concentrations in millimolar order and over the range $18.75-150 \mu \mathrm{g} \mathrm{mL}^{-1}$, respectively. The present sensor would be a distinct demonstration for producing quantitative dual-assays for various biomolecules used for clinical diagnoses.
\end{abstract}

Keywords Dual-electrochemical sensor, immunochromatography, lateral flow, quantitative detection, enzyme label

(Received February 26, 2015; Accepted April 1, 2015; Published July 10, 2015)

\section{Introduction}

Quantitative point-of-care immunoassays have attracted considerable attention for clinical diagnoses in the bedside. An immunochemical test-strip assay, immunochromatography, which combines the immunorecognition event of the target molecules with the capillary flow, is well-established and widely used to fabricate diagnostic devices. ${ }^{1,2}$ The antibody conjugated with the signal source, which was stocked at the halfway position of the membrane, was also migrated with target molecules to form immunocomplexes at the antibody immobilized area with the corresponding antigen-antibody recognition and concentrated on there within 10-20 min. Moreover, the unreacted signal source was spontaneously removed to downstream in the membrane strips, and automatically discriminated from the captured molecules. This technique with both properties for the concentration of analytes and separation of the unreacted signal source provides a simple and rapid immunosensing platform.

A visual colorimetric measurement by nacked eye is commonly utilized for the decision of positivity or negativity, but is of low sensitivity, and thus insufficient for quantitative analysis. Recently, optical colorimeters and readers were developed to detect the amount of analytes by image-processing of the color intensity. ${ }^{3,4}$ An electrochemical detection system is particularly attractive for membrane- and paper-based microfluidics owing to its simple instrumentation with high sensitivity and portability. In the field of microfluidic paperbased analytical devices ( $\mu$ PADs), which were introduced by

† To whom correspondence should be addressed.

E-mail: yasu@sci.u-hyogo.ac.jp
Whitesides' group, ${ }^{5,6}$ an electrochemical detection was adopted for the quantitative purpose. Microfluidic paper-based electrochemical devices ( $\mu$ PEDs), which are categorized in $\mu$ PADs with electrochemical systems, were applied to detect glucose, ${ }^{7-10}$ lactate,,${ }^{8,10}$ cholesterol, ${ }^{8}$ uric acid, ${ }^{10,11}$ and ascorbic acid $^{11}$ based on enzyme reactions, and may be used for immunosensing shortly.

Electrochemical systems have been incorporated in lateral flow immunochromatographic assays for the sensitive and quantitative determination of target molecules. Labels for immunorecognition events were reported to produce electrochemical signals and to enhance the sensitivity, including gold nanoparticle, ${ }^{12}$ quantum dot, ${ }^{13-16}$ enzyme, ${ }^{17-20}$ and liposome. ${ }^{21}$ However, labels accumulated in the region immobilized with some antibodies must be transferred to an electrochemical cell to convert the labels to the electrochemical signal. Thus, we reported electrochemical immunochromatography by the direct detection of a redox species flowing in a nitrocellulose membrane with a microelectrode contacted to the membrane surface. ${ }^{22}$

In this research, we used albumin and creatinine to demonstrate the advantages of electrochemical immunochromatography. Urinary albumin is an important clinical marker in patients with diabetic nephropathy, renal failure and cardiovascular disease..$^{23}$ Semiquantitative dipsticks ${ }^{24,25}$ and immunologically-based assay $^{26,27}$ have been traditionally used to determine albumin in urine. Simple and highly sensitive photospectrometric determination methods have also been developed based a dyebinding reaction on membrane films for point-of-care testing. ${ }^{28-30}$ The threshold concentration required to detect urinary albumin is $30 \mu \mathrm{g} \mathrm{mL}^{-1} .30 \quad$ However, the variability in the albumin excretion rate throughout a day is impeding accurate albumin measurements. ${ }^{31}$ Therefore, urinary albumin excretions are 


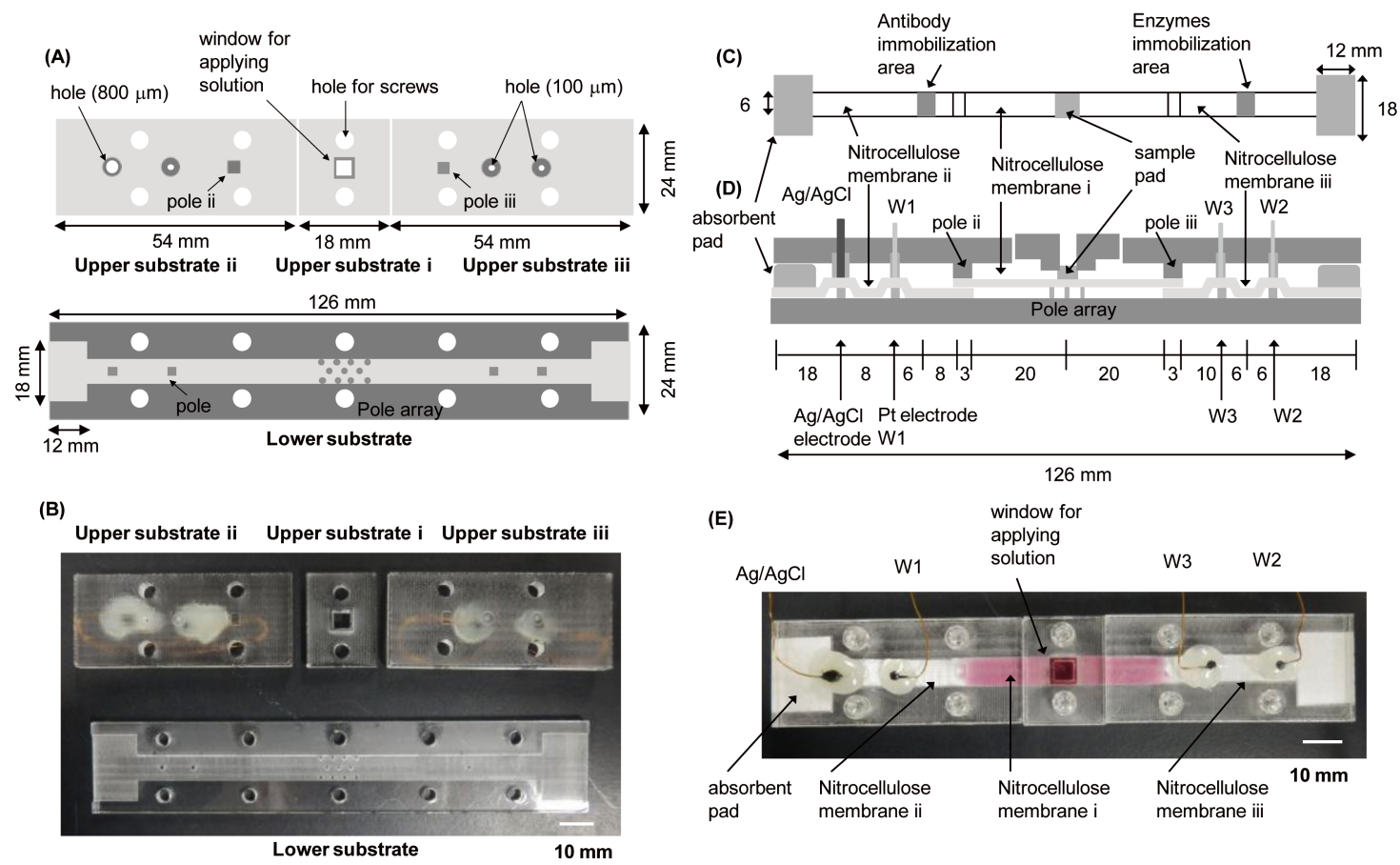

Fig. 1 Schematic illustrations and photographs of the dual electrochemical sensor based on the test strip. (A) Illustration and (B) photograph of the upper substrates i, ii, and iii and the lower substrate. (C) Test strip consisted of three nitrocellulose membranes with the immobilization area for three enzymes and antibody immobilization area, sample pad and absorbent pads. (D) Cross-sectional view of the immunochromatographic system with nitrocellulose membranes between plates with electrodes and poles. (E) Photograph of the immunochromatographic device.

corrected by the creatinine concentrations, albumin-to-creatinine ratios, for the albuminuria tests in random urine, because the 24-h creatinine excretion can be estimated based on the gender, age and weight of patients. ${ }^{32,33}$ The concentration level of creatinine in urine is millimolar level. ${ }^{34}$ The most commonly used methods for creatinine determination are based on enzymatic colorimetry. ${ }^{35}$ Enzyme-based biosensors by using three enzymes ${ }^{36-38}$ (creatininase, creatinase, and sarcosine oxidase) have also been developed for the measuring creatinine concentrations.

We fabricated a dual electrochemical sensor based on a teststrip assay for the determination of albumin and creatinine in a solution. Each nitrocellulose membrane immobilized antibody and enzymes was prepared in the left side and right side of the fluidic devices, respectively. The solution containing albumin and creatinine was applied to the membrane from the center of the device to flow equally to both immobilization regions. The hydrogen peroxide generated by three enzymes was oxidized at the electrode prepared downstream from the enzyme immobilization region to detect the creatinine concentration. The oxidation current of $\mathrm{Fe}(\mathrm{CN})_{6}{ }^{4}$ generated by the enzyme reaction of glucose oxidase (GOx) used as a label for immunoreactions was used to detect the albumin concentration. Moreover, another electrode was arranged before the immobilization region for three enzymes to cancel the effect of the direct oxidation of oxidizable species, such as ascorbic acid and uric acid containing urine samples. The present electrochemical immunochromatographic assay allowed for the quantitative determination of albumin and creatinine in a test sample.

\section{Experimental}

\section{Materials and reagents}

Acrylic plates were purchased from Mitsubishi Rayon Co., Ltd. (Tokyo, Japan). Platinum $(50 \mu \mathrm{m}$ diameter) and silver (500 $\mu \mathrm{m}$ diameter) wires were purchased from Nilaco Co., Ltd. (Tokyo, Japan). Nitrocellulose membrane (Hi-Flow ${ }^{\mathrm{TM}}$ Plus, HF180), nitrocellulose membrane with the polyester backing (Hi-Flow ${ }^{\mathrm{TM}}$ Plus, HF240), sample pad and absorbent pad (Sure Wick $^{\circledR}$ ) were purchased from Millipore Co., Ltd. (Bedford, MA). Monoclonal mouse anti-human albumin antibody (albumin antibody), polyclonal anti-human albumin antibody labeled with glucose oxidase (GOx labeled antibody) and albumin were purchased from Sigma. The enzymes used for measuring creatinine were creatininase $\left(256 \mathrm{U} \mathrm{mg}^{-1}\right.$, Toyobo Co., Ltd., Tokyo, Japan), creatinase (13 $\mathrm{U} \mathrm{mg}^{-1}$, Toyobo), and sarcosine oxidase (16.5 $\mathrm{U} \mathrm{mg}^{-1}$, Toyobo). Casein, potassium ferrocyanide and potassium ferricyanide were obtained from Wako Pure Chemicals (Osaka, Japan). All other chemicals used were analytical reagents or laboratory grade.

\section{Preparation of a device for electrochemical immunochromato- graphy}

A device (24 mm wide) that was used for the electrochemical detection of target molecules and supports of the test strip consisted of three parts of upper acrylic substrates i, ii and iii (5 $\mathrm{mm}$ thickness), and a lower acrylic substrate (3 mm thickness). A laser-beam fabrication system (VLS2.30, Universal Laser Systems Inc., Scottsdale, AZ) was used to fabricate poles and holes in each substrate. Figures 1(A) and 1(B) show the schematic design and a photograph for the 
fabricated upper and lower substrates, respectively. The white and light-gray colors represent the hollowed and engraved regions with $350 \mu \mathrm{m}$ depth, respectively. The square window $(6 \times 6 \mathrm{~mm})$ in the square pole $(10 \times 10 \mathrm{~mm})$ in the upper substrate i (18 mm long) was used to apply a sample solution containing target molecules. A square pole $(3 \times 2 \mathrm{~mm})$ and two circular poles ( $3 \mathrm{~mm}$ diameter) with circular holes were prepared in each upper substrate ii and iii (54 mm long). The square poles were used to fix the junction with two nitrocellulose membranes. A hole of $800 \mu \mathrm{m}$ in diameter was prepared in the center of the pole of the left side in the upper substrate ii, and holes of $100 \mu \mathrm{m}$ in diameter were located in the center of the pole in three other circular poles in the upper substrate ii and iii. To fabricate disk electrodes, platinum wires ( $50 \mu \mathrm{m}$ in diameter) were inserted into each $100 \mu \mathrm{m}$ hole and glued with an adhesive agent. Silver wire $(500 \mu \mathrm{m}$ in diameter $)$ was also inserted into an $800 \mu \mathrm{m}$ hole. After polishing and cleaning, the surface of the silver was electrochemically oxidized in $0.1 \mathrm{~mol} \mathrm{dm}^{-3}$ hydrochloric acid for $20 \mathrm{~s}$, and used as a pseudo-reference/ counter electrode.

The groove ( $6 \mathrm{~mm}$ wide) used as a support for the test strip was prepared in the lower substrate. An array of eleven poles was fabricated in the center of the groove. Each pole was $1 \mathrm{~mm}$ in diameter and placed at a distance of $2 \mathrm{~mm}$ from adjacent poles. Four other poles (1 mm square) were also prepared at positions corresponding to the electrodes when the four components were assembled to complete the device. The containers (18 mm wide and $12 \mathrm{~mm}$ long) prepared at both ends on the lower substrate were used for the storage of absorbent pads. Ten holes ( $6 \mathrm{~mm}$ diameter) were used for screws to fix the upper and lower substrates.

\section{Preparation of the immunochromatographic test strip}

The test strip consists of six components: a sample pad, nitrocellulose membranes i, ii and iii, and two absorbent pads. An anti-albumin antibody and three enzymes for creatinine measurements were immobilized on a nitrocellulose membrane, ii and iii, with a polyester backing $(6 \mathrm{~mm}$ wide, $43 \mathrm{~mm}$ long, and $185 \mu \mathrm{m}$ thick), respectively. The phosphate buffer $\left(50 \mathrm{mmol} \mathrm{dm}^{-3}, 4 \mu \mathrm{L}, \mathrm{pH} 7.5\right)$ containing $0.6 \mu \mathrm{g} \mathrm{mL}^{-1}$ antialbumin antibody was injected by the pulse injection system (PulseInjector, Cluster Technology Co., Ltd, Osaka, Japan) at $11 \mathrm{~mm}$ from the edge in the upstream direction on membrane ii. The top of the injector was set $1 \mathrm{~mm}$ above the membrane and scanned four times at $300 \mu \mathrm{m} \mathrm{s}^{-1}$. The solution injection rate was set at $25 \mathrm{~nL} \mathrm{~s}^{-1}$. The membranes were kept in a desiccator with silica gel (Nacalai Tesque, Kyoto, Japan) for $3 \mathrm{~h}$ at room temperature to ensure immobilization of the antibody. The membranes were then incubated in the blocking solution $\left(50 \mathrm{mmol} \mathrm{dm}{ }^{-3}\right.$ boric acid buffer containing $0.5 \% \mathrm{w} / \mathrm{w}$ casein, $\mathrm{pH} 8.5$ ) for $30 \mathrm{~min}$ at room temperature to prevent any nonspecific adsorption of proteins during subsequent steps. After washing with $50 \mathrm{mmol} \mathrm{dm}^{-3}$ Tris- $\mathrm{HCl}$ buffer containing $0.5 \%$ $\mathrm{w} / \mathrm{w}$ saccharose and $0.05 \% \mathrm{w} / \mathrm{w}$ sodium chloride $(\mathrm{pH} 7.5)$ for $30 \mathrm{~min}$ at room temperature, the membranes were dried in the desiccator for over $12 \mathrm{~h}$, and stored in an aluminum bag at $4^{\circ} \mathrm{C}$ when not in use.

The phosphate buffer $\left(10 \mathrm{mmol} \mathrm{dm}^{-3}, \quad 5 \mu \mathrm{L}, \quad \mathrm{pH} 8.0\right)$ containing $2.4 \mathrm{kU} \mathrm{mL}^{-1}$ creatininase, $2.4 \mathrm{kU} \mathrm{mL}^{-1}$ creatinase, $2.9 \mathrm{kU} \mathrm{mL}^{-1}$ sarcosine oxidase, $1.0 \mathrm{mg} \mathrm{mL}^{-1}$ bovine serum albumin (BSA), and $2.5 \mathrm{mmol} \mathrm{dm}^{-3}$ glutaraldehyde was dropped on membrane iii, $19 \mathrm{~mm}$ from the edge in the upstream direction. The membranes were dried in a desiccator for over $12 \mathrm{~h}$ at $4^{\circ} \mathrm{C}$ and stored in an aluminum bag at $4^{\circ} \mathrm{C}$.

Figures 1(C) and 1(D) show schematic illustrations of the test strip for electrochemical immunochromatography and the crosssectional view of the device incorporated with test strip. Membrane ii immobilized with the albumin antibody was placed on the lower substrate along the groove with double-sided tape from the left end. Membrane iii, immobilized on three enzymes, was also placed from the right end. Absorbent pads, $12 \mathrm{~mm}$ long and $18 \mathrm{~mm}$ wide, were placed on both ends of the lower substrate. Nitrocellulose membrane i without any backing (46 mm long) was positioned on the center of the lower substrate. Membrane ii and iii were positioned left and right sides of membrane i by $3 \mathrm{~mm}$ overlap. The sample pad $(6 \times$ $6 \mathrm{~mm}$ ) was laid on the center of membrane i. Three parts of the upper substrates (i, ii, and iii) were mounted on the lower substrate with the test strip and fixed with screws.

The sample pad and membrane i were sandwiched between the lower pole array and the window on the upper substrate I, from which the sample solution was loaded. Poles ii and iii were used as supports for the overlapped membranes i and ii, and membranes $\mathrm{i}$ and iii. Four square poles on membranes ii and iii were used to ensure contact of the electrodes to the fluids into membranes ii and iii.

\section{Electrochemical measurements}

Platinum electrodes inserted into holes fabricated in the upper substrates ii and iii were polished with a $5 \mu \mathrm{m}$ alumina slurry. After washing with pure water, the surfaces were cleaned with an oxygen plasma asher (Plasma Asher, Yanako New Science Inc., Kyoto, Japan) at $30 \mathrm{~W}$ for $30 \mathrm{~s}$. The platinum electrode on substrate ii was used as a working 1 (W1) to detect the albumin captured on the antibody immobilization area with immunoreactions. Right and left platinum electrodes on substrate iii were used as a working 2 (W2) and 3 (W3) to detect the creatinine by sequential reactions of three enzymes and ascorbic acid, a typical electroactive interference, respectively. $\mathrm{W} 1, \mathrm{~W} 2$ and $\mathrm{W} 3$ were $37 \mathrm{~mm}$ left, $45 \mathrm{~mm}$ right and $33 \mathrm{~mm}$ right from the center of the device. $\mathrm{Ag} / \mathrm{AgCl}$ electrode ( $45 \mathrm{~mm}$ left from the center) was used as a pseudoreference/counter electrode. In this study, a simple twoelectrode configuration was adopted because the potential of a pseudo-reference electrode was stable in the flowing system of a solution containing a constant concentration of $\mathrm{Cl}^{-}$. Antibody and enzymes were immobilized $31 \mathrm{~mm}$ left and $39 \mathrm{~mm}$ right from the center. All electrochemical experiments made use of an electrochemical analyzer (HZ-5000, Hokuto Denko Corp., Tokyo, Japan). Amperometry measurements were performed to detect the albumin, creatinine, and ascorbic acid.

\section{Electrochemical determination of albumin and creatinine}

We applied the electrochemical detection of albumin and creatinine flowing in a test strip. Figure 2 shows the principle of electrochemical detection based on an immunochromatigraphic device. A solution containing different concentrations of albumin and creatinine $(60 \mu \mathrm{L})$ is applied to a window positioned in the center of the test strip (Fig. 2(A)). The added solution starts to migrate toward both the left and right ends of the test strip by the capillary force. When albumin arrives at the antibody immobilization area in membrane ii, immunocomplexes are formed to capture albumin in that area (Fig. 2(B)). In membrane iii, the arrival of creatinine to the immobilization area of enzymes causes the generation of hydrogen peroxide. The potential of $\mathrm{W} 2$ is applied to $0.7 \mathrm{~V}$ in order to oxidize hydrogen peroxide at $6.5 \mathrm{~min}$. GOx-labeled antibody $(1 / 500$ diluted, $60 \mu \mathrm{L}$ ) in the second migration, which is introduced at $3 \mathrm{~min}$, is also captured at the antibody immobilization area in the membrane ii to form a sandwich structure (Fig. 2(C)). Then, 
(A)

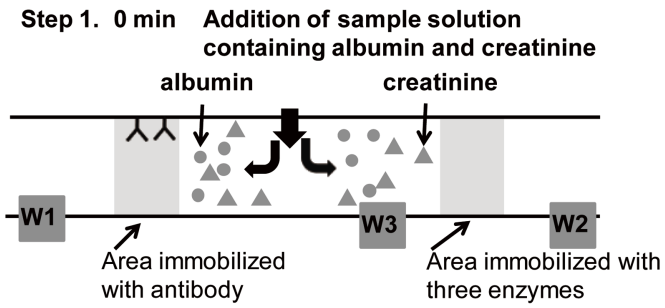

(B) Step 2. $3 \mathrm{~min} \quad$ Addition of solution containing GOx-labeled antibody

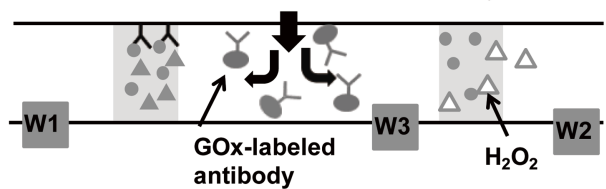

(C) Step 3. $6.5 \mathrm{~min} \quad$ Application of voltage (0.7 V) to W2 for creatinine measurement

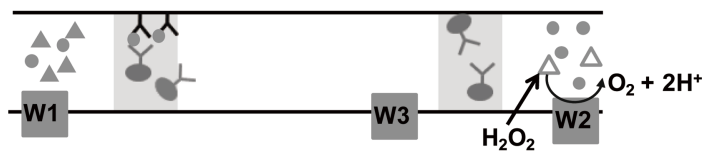

(D) Step 4. $14 \mathrm{~min} \quad$ Addition of $\mathrm{Fe}(\mathrm{CN})_{6}{ }^{3-}$ and glucose

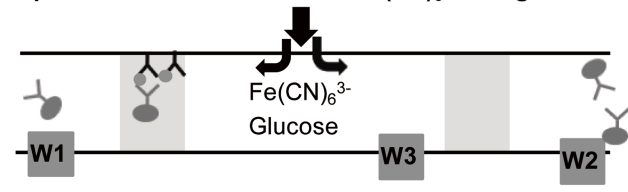

(E)

Step 5. $16.5 \mathrm{~min} \quad$ Application of voltage $(0.5 \mathrm{~V})$ to $\mathrm{W} 1$ for albumin measurement

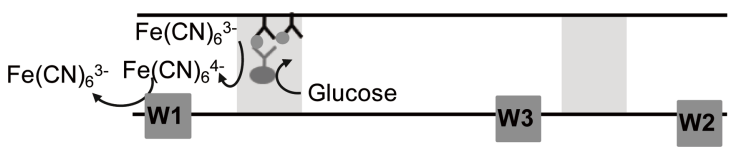

Fig. 2 Principle of the electrochemical detections of creatinine and albumin with the dual electrochemical sensor. (A) The solution containing different concentrations of albumin and creatinine was added to the window positioned in the center of the test strip. (B) Hydrogen peroxide was generated by the enzyme reactions of creatinine, albumin was trapped at the antibody immobilization area, and a GOx-labeled antibody was introduced. (C) The generated hydrogen peroxide was oxidized at W2 and the captured albumin was labeled with a GOx-labeled antibody. (D) Substrates for the enzyme reaction, $\mathrm{Fe}(\mathrm{CN})_{6}{ }^{4}$, and glucose were introduced. (E) $\mathrm{Fe}(\mathrm{CN})_{6}{ }^{4}$ produced by the enzyme reaction of GOx was detected with $\mathrm{W} 1$.

we add the substrates for the labeled enzyme (GOx), $50 \mathrm{mmol}$ $\mathrm{dm}^{-3}$ glucose and $5.0 \mathrm{mmol} \mathrm{dm}{ }^{-3} \mathrm{Fe}(\mathrm{CN})_{6}{ }^{3-}$ at $14 \mathrm{~min}$ (Fig. 2(D)). The excess GOx-labeled antibody is automatically removed to the downstream part by this step, and $\mathrm{Fe}(\mathrm{CN})_{6}{ }^{4}$ is produced by the enzyme reaction of captured GOx in the area (Fig. 2(E)). Finally, we applied a voltage of $0.5 \mathrm{~V}$ to $\mathrm{W} 1$ in order to detect the oxidation current of the generated $\mathrm{Fe}(\mathrm{CN})_{6}{ }^{4-}$ at $16.5 \mathrm{~min}$ (Fig. 2(E)).

\section{Results and Discussion}

\section{Fluid flow in the test strip}

We investigated fluid flow in a test strip incorporated into the electrochemical immunochromatographic device. When phosphate buffered saline (PBS, $100 \mathrm{mmol} \mathrm{dm}^{-3}$ phosphate

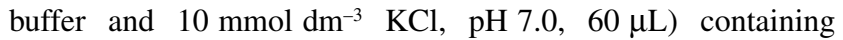

$4.0 \mathrm{mmol} \mathrm{dm}^{-3} \mathrm{Fe}(\mathrm{CN})_{6}{ }^{4-}$ was applied from the window, the solution in membrane $i$ was propelled to downstream of both the left and right directions with approximately identical flow rate by the capillary force $(13 \mathrm{~mm} / \mathrm{min})$. Figure $1(\mathrm{E})$ shows a photograph of the device $1.5 \mathrm{~min}$ after the PBS was applied. The fluids were reached at the overlapped regions between membranes i and ii, and membrane i and iii, and then transferred to membranes ii and iii. PBS containing $4.0 \mathrm{mmol} \mathrm{dm}^{-3}$ $\mathrm{Fe}(\mathrm{CN})_{6}{ }^{4-}(60 \mu \mathrm{L})$ were again applied at $3 \mathrm{~min}$. The left and right fluids were reached at the $\mathrm{Ag} / \mathrm{AgCl}$ electrode and $\mathrm{W} 2$ at approximately $6 \mathrm{~min}$. Another PBS with $\mathrm{Fe}(\mathrm{CN})_{6}{ }^{4-}(60 \mu \mathrm{L})$ was applied at $14 \mathrm{~min}$. The fluids flowed satisfactory for $50 \mathrm{~min}$ without any leakage from the test strip.

Characterization of electrochemical behavior of the device

Cyclic voltammetry (CV) was performed by using W1, W2 and $\mathrm{W} 3$ in a PBS solution containing $4.0 \mathrm{mmol} \mathrm{dm}^{-3} \mathrm{Fe}(\mathrm{CN})_{6}{ }^{4}$ (Fig. S1A, Supporting Information). The $\mathrm{Ag} / \mathrm{AgCl}$ electrode with a $3 \mathrm{~mol} \mathrm{dm}^{-3} \mathrm{KCl}$ solution was used as a reference electrode. Almost identical current curves were observed from $\mathrm{W} 1$ and W2. The small response obtained from W3 may be due to the small area of platinum exposed to the solution. Figure S1B (Supporting Information) shows voltammograms of $4.0 \mathrm{mmol} \mathrm{dm}{ }^{-3} \mathrm{Fe}(\mathrm{CN})_{6}{ }^{4-}$ flowing in the test strip measured by using an $\mathrm{Ag} / \mathrm{AgCl}$ electrode in substrate ii as a reference electrode. The potential was scanned 6 min after a solution containing $\mathrm{Fe}(\mathrm{CN})_{6}{ }^{4-}$ was applied. For $\mathrm{CV}$ measurements, the potential of the platinum electrodes was scanned at $20 \mathrm{mV} / \mathrm{s}$ between -0.2 and $0.6 \mathrm{~V}$ versus the $\mathrm{Ag} / \mathrm{AgCl}$ electrode in substrate ii. The almost steady-state oxidation currents of $\mathrm{Fe}(\mathrm{CN})_{6}{ }^{4-}$ were observed at a positive potential due to the continuous supply of PBS flow containing $\mathrm{Fe}(\mathrm{CN})_{6}{ }^{4}$. The steady-state currents obtained from $\mathrm{W} 1$ and $\mathrm{W} 2$ were nearly identical. Therefore, the distance between the working electrode and pseudo reference electrode has no serious influence on electrochemical measurements in this device structure.

Electrochemical determination of creatinine by detecting hydrogen peroxide generated with the reactions of three enzymes We investigated the amperometric responses of hydrogen peroxide generated by the reactions of three enzymes immobilized on membrane iii. Figure 3(A) shows amperograms obtained $6.5 \mathrm{~min}$ after adding different concentrations of creatinine and $150 \mu \mathrm{g} \mathrm{mL}^{-1}$ albumin from the window in the device. After the solution arrived at $\mathrm{W} 2$ and the $\mathrm{Ag} / \mathrm{AgCl}$ electrode at approximately $6 \mathrm{~min}$, the potential of W2 was stepped up to $0.7 \mathrm{~V}$. Spike-like oxidation currents were observed immediately after the potential was applied; subsequently, the oxidation currents showed a gradual decrease to reach almost steady-state in $20 \mathrm{~s}$, followed by a decrease down to another plateau region in $2 \mathrm{~min}$. This first plateau was attributed to the time required flow through the region of immobilized enzymes. The unstable oxidation currents during the first plateau would be caused by removal of the immobilized enzymes, a difference of the immobilized areas of enzymes and inhomogeneous flows through the immobilized areas. The average currents at between 6.7-6.9 min were used as amperometric responses for the calibration curve. Figure 3(B) shows these current responses as a function of the creatinine concentrations. The results indicate that the response almost linearly increases with increasing concentration owing to increase of the hydrogen peroxide generated by reactions of immobilized enzymes, leveling out at higher concentration. A good correlation between the creatinine concentration and current response was obtained in millimolar order of creatinine. In addition, after the currents of hydrogen 
(A)

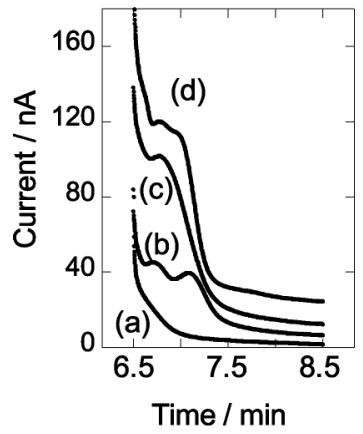

(B)

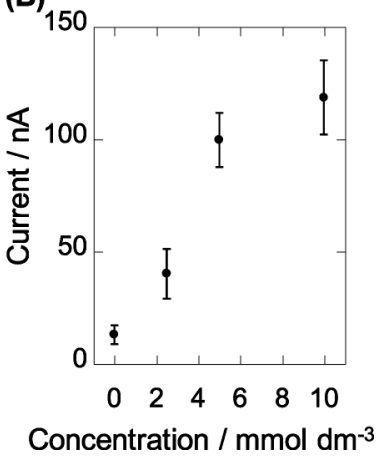

Fig. 3 (A) Current-time curves upon the addition of different concentrations of creatinine to the device. A potential of $0.7 \mathrm{~V} v s$. the pseudo-reference electrode was applied to W2. The concentrations of creatinine: (a) 0 , (b) 2.5 , (c) 5.0 , and (d) $10.0 \mathrm{mmol} \mathrm{dm}^{-3}$. (B) Calibration curves for creatinine.

peroxide were measured by $\mathrm{W} 2$, the oxidation currents of $\mathrm{Fe}(\mathrm{CN})_{6}{ }^{4-}$ were obtained to detect albumin by $\mathrm{W} 1$, resulting in identical responses $(8.9 \pm 0.7 \mathrm{nA})$ that were observed upon the addition of solutions containing $150 \mu \mathrm{g} \mathrm{mL}^{-1}$ albumin with different concentrations of creatinine (Fig. S2, Supporting Information). Therefore, the presence of the albumin does not inhibit the creatinine determination by the present system. The details for the albumin measurement are described in the following section.

Electrochemical determination of albumin by detecting $\mathrm{Fe}(\mathrm{CN})_{6}^{4-}$ generated by the enzyme reaction of GOx

We investigated the amperometric responses of $\mathrm{Fe}(\mathrm{CN})_{6}{ }^{4-}$ generated by the enzyme reaction of GOx-labeled antibody captured on the antibody immobilization area. Solutions containing different concentrations of albumin and $10.0 \mathrm{mmol}$ $\mathrm{dm}^{-3}$ creatinine, and solutions containing GOx-labeled antibody were subsequently added to the device from the window at 0 and $3 \mathrm{~min}$, respectively. The solution containing the substrates for the enzyme reaction of $\mathrm{GOx}$, glucose and $\mathrm{Fe}(\mathrm{CN})_{6}{ }^{3-}$ was then added at $14 \mathrm{~min}$, and a voltage of $0.5 \mathrm{~V}$ was applied to $\mathrm{W} 1$ at $16.5 \mathrm{~min}$. Figure 4(A) shows the amperometric responses obtained with the test strip treated with different concentrations of albumin. The oxidation current dramatically increased approximately $12 \mathrm{~min}$ (at $28.5 \mathrm{~min}$ ) after the potential was stepped, and then reached to almost steady-state. When the substrates for GOx arrived at the antibody immobilization area where the GOx-labeled antibody was captured by the formation of sandwich-type immunocomplexes, $\mathrm{Fe}(\mathrm{CN})_{6}{ }_{6}^{4-}$ was produced by the enzyme reaction. The generated $\mathrm{Fe}(\mathrm{CN})_{6}{ }^{4-}$ flowed to oxidize at W1. The average currents obtained at between 35 $40 \mathrm{~min}$ were used as the responses for the calibration plot. Figure 4(B) shows the calibration curve obtained upon immunochromatography of increasing concentrations of albumin. The current response increased with increasing the concentration of albumin. This result indicates that the amount of captured albumin in the immobilization area increased with increasing concentration of albumin. A good correlation between the albumin concentration and the current response was obtained in the range of $18.75-150 \mu \mathrm{g} \mathrm{mL}^{-1}$. The oxidation currents of hydrogen peroxide were measured to determine the creatinine level by W2 before measuring albumin by $\mathrm{W} 1$ ( $6.5 \mathrm{~min}$ after the addition of the solutions). Identical oxidation currents $(110.4 \pm 8.4 \mathrm{nA})$ were observed from the addition of

(A)

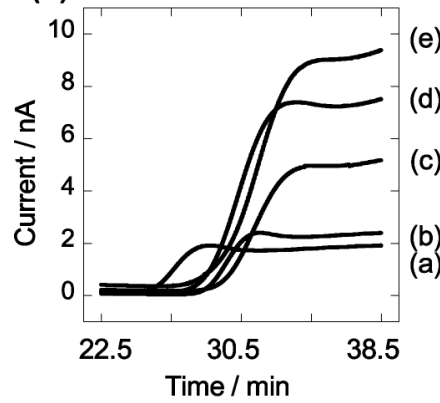

(B)

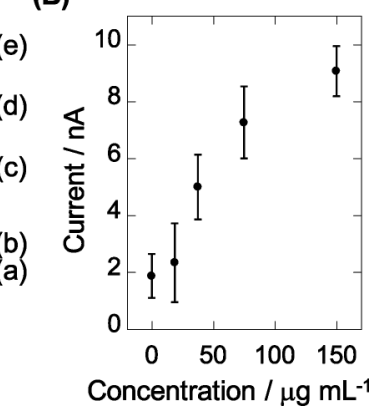

Fig. 4 (A) Amperometric responses based on the oxidation current of $\mathrm{Fe}(\mathrm{CN})_{6}{ }^{4-}$ generated by the enzymatic reaction of labeled-GOx captured on a nitrocellulose membrane with immunoreaction. Amperometric measurements were carried out at $0.5 \mathrm{~V} v s$. the pseudoreference electrode by flowing $5.0 \mathrm{mmol} \mathrm{dm}^{-3} \mathrm{Fe}(\mathrm{CN}) 6^{3-}, 50 \mathrm{mmol}$ $\mathrm{dm}^{-3}$ glucose. The concentrations of albumin: (a) 0 , (b) 18.75 , (c) 37.50 , (d) 75.00 , and (e) $150.0 \mu \mathrm{g} \mathrm{mL}^{-1}$. (B) Calibration curves obtained upon immunoreaction of a constant concentration of GOxlabeled antibody and different concentrations of analyte albumin.
(A)

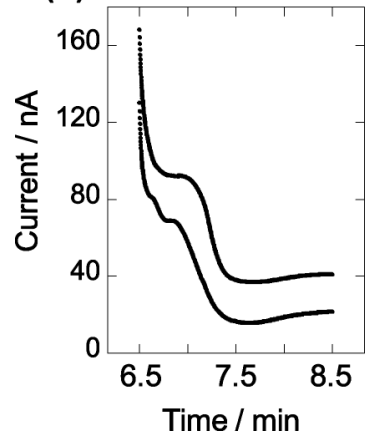

(B)

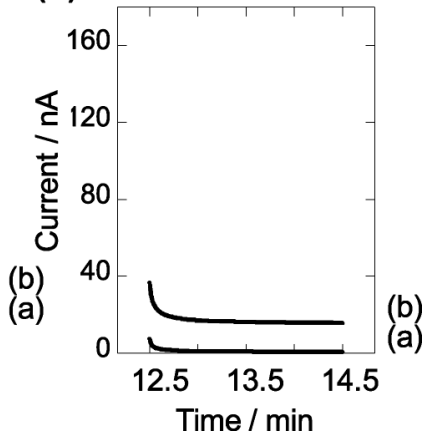

Fig. 5 (A) Current-time curves obtained by (A) W2 and (B) W3 upon the addition of $10.0 \mathrm{mmol} \mathrm{dm}^{-3}$ creatinine to chromatographic device. The concentrations of ascorbic acid: (a) 0 and (b) $1.0 \mathrm{mmol}$ $\mathrm{dm}^{-3}$.

solutions containing $10.0 \mathrm{mmol} \mathrm{dm}{ }^{-3}$ creatinine with different concentrations of albumin (Fig. S3, Supporting Information). The obtained responses were indeed consistent with the responses obtained in Fig. 3(A)d. For non-electroactive species, creatinine does not disturb the electrochemical detection of $\mathrm{Fe}(\mathrm{CN})_{6}{ }^{4-}$ generated by the reaction of the labeled enzyme.

The total measurement time required with the present system is around $40 \mathrm{~min}$, which is twice that of conventional immunochromatographic formats. The time required for the dual-assay could be reduced by using a multipotentiostat. The pleasant electrochemical system beads on the enzyme reactions and immunoreactions with enzyme labels would be a distinct demonstration for producing immnochromatographic assays for the various biomolecules for clinical diagnoses.

\section{Electrochemical detection of ascorbic acid}

Oxidation currents were obtained in a flowing solution containing creatinine and ascorbic acid at W2 and W3 placed downstream and upstream from the enzymes immobilization region, respectively (Fig. 1(D)). Figure 5 shows oxidation responses obtained by flowing a solution containing $10.0 \mathrm{mmol}$ $\mathrm{dm}^{-3}$ creatinine and in both the presence and absence of 
$1.0 \mathrm{mmol} \mathrm{dm}^{-3}$ ascorbic acid. In the absence of ascorbic acid, no current response was observed from W3 (Fig. 5(B)a), while the oxidation response was observed from W2 (Fig. 5(A)a), which was similar to that obtained in Fig. 3(A). This is due to the oxidation of hydrogen peroxide generated by reactions of three enzymes. On the other hand, the responses obtained by W2 and W3 in the presence of ascorbic acid were at higher currents than those obtained in the absence of ascorbic acid (Figs. 5(A)b and 5(B)b). The currents increased with the same values and without changing the shapes, since ascorbic acid was directly oxidized at both W2 and W3. The results indicate that the interference in the measurement of urine by electrochemically oxidizable species, such as ascorbic acid and uric acid, would be corrected by the difference of the currents obtained by electrodes placed before and beyond the immobilization area for enzymes.

\section{Conclusions}

We demonstrated the feasibility of this dual electrochemical sensor based on immunochromatography for the determination of albumin and creatinine both simply and quantitatively. The fabricated device consisted of test strips with an antibody immobilization area for albumin assay and the immobilization area of three enzymes for a creatinine assay that was sandwiched between a lower substrate and upper substrates with the window used for applying the solution, three working electrodes, and an $\mathrm{Ag} / \mathrm{AgCl}$ electrode. The solution added from the window arranged in the center of the device was propelled to downstream of both the left and right directions with the approximately identical flow rate by the capillary force. Hydrogen peroxide generated by the reaction of three enzymes (creatininase, creatinase, and sarcosine oxidase) was oxidized by the electrode contacted to the nitrocellulose membrane for the detection of creatinine. Albumin was trapped in the antibody immobilization area and labeled with GOx to reduce the electron mediator, $\mathrm{Fe}(\mathrm{CN})_{6}{ }^{3-}$, so as to produce the signal source, $\mathrm{Fe}(\mathrm{CN})_{6}{ }^{4-}$. Both oxidation currents were increased with increasing concentrations of creatinine and albumin in a solution. However, stepwise additions of labeled enzyme and substrates for the enzyme reaction are required for the process of immunosensing in this sensor. We will produce an immunochromatography device with the quantitative and single-step analysis system by storing the objects required for the assay at halfway positions in the fluid stream.

\section{Acknowledgements}

This work was partly supported by JSPS KAKENHI Grant No. 26288071.

\section{Supporting Information}

Cyclic voltammograms obtained by electrodes in the device are shown in Fig. S1. Amperometric responses for the constant concentration of albumin in the different concentrations of creatinine and the constant concentration of creatinine in the different concentrations of albuminb are shown in Figs. S2 and S3, respectively. These materials are available free of charge on the Web at http://www.jsac.or.jp/analsci/.

\section{References}

1. F. Tsagkogeorgas, M. Ochsenkuhn-Petropoulou, R. Niessner, and D. Knopp, Anal. Chim. Acta, 2006, 573 - 574, 133.

2. R. F. Zuk, V. K. Ginsberg, T. Houts, J. Rabbie, H. Merrick, E. F. Ullman, M. M. Fischer, C. C. Sizto, S. N. Stiso, and D. J. Litman, Clin. Chem., 1985, 31, 1144.

3. X. Mao, Y. Ma, A. Zhang, L. Zhang, L. Zeng, and G. Liu, Anal. Chem., 2009, 81, 1660.

4. A. K. Ellerbee, S. T. Phillips, A. C. Siegel, K. A. Mirica, A. W. Martinez, P. Striehl, N. Jain, M. Prentiss, and G. M. Whitesides, Anal. Chem., 2009, 81, 8447.

5. A. W. Martinez, S. T. Phillips, M. J. Butte, and G. M. Whitesides, Angew. Chem., Int. Ed., 2007, 46, 1318.

6. A. W. Martinez, S. T. Phillips, G. M. Whitesides, and E. Carrilho, Anal. Chem., 2010, 82, 3.

7. W. Dungchai, O. Chailapakul, and C. S. Henry, Analyst, 2011, 136, 77.

8. Z. Nie, F. Deiss, X. Liu, O. Akbulut, and G. M. Whitesides, Lab Chip, 2010, 10, 3163.

9. Z. Nie, C. A. Nijhuis, J. Gong, X. Chen, A. Kumachev, A. W. Martinez, M. Narovlyansky, and G. M. Whitesides, Lab Chip, 2010, 10, 477.

10. W. Dungchai, O. Chailapakul, and C. S. Henry, Anal. Chem., 2009, 81, 5821.

11. R. F. Carvalhal, M. Simaõ Kfouri, M. H. de Oliveira Piazetta, A. L. Gobbi, and L. T. Kubota, Anal. Chem., 2010, $82,1162$.

12. X. Mao, M. Baloda, A. S. Gurung, Y. Lin, and G. Liu, Electrochem. Commun., 2008, 10, 1636.

13. H. Niana, J. Wang, H. Wu, J.-G. Lo, K.-H. Chiu, J. G. Pounds, and Y. Lin, Anal. Chim. Acta, 2012, 713, 50.

14. Q. Yang, X. Gong, T. Song, J. Yang, S. Zhu, Y. Li, Y. Cui, Y. Li, B. Zhang, and J. Chang, Biosens. Bioelectron., 2011, 30, 145.

15. Y.-Y. Lin, J. Wang, G. Liu, H. Wu, C. M. Wai, and Y. Lin, Biosens. Bioelectron., 2008, 23, 1659.

16. G. Liu, Y.-Y. Lin, J. Wang, H. Wu, C. M. Wai, and Y. Lin, Anal. Chem., 2007, 79, 7644.

17. D. Du, J. Wang, L. Wang, D. Lu, and Y. Lin, Anal. Chem., 2012, 84, 1380.

18. Z.-X. Zou, J. Wang, H. Wang, Y.-Q. Li, and Y. Lin, Talanta, 2012, 94, 58.

19. L. Wang, D. Lub, J. Wang, D. Du, Z. Zou, H. Wang, J. N. Smith, C. Timchalk, F. Liu, and Y. Lin, Biosens. Bioelectron., 2011, 26, 2835.

20. K. Inoue, P. Ferrante, Y. Hirano, T. Yasukawa, H. Shiku, and T. Matsue, Talanta, 2007, 73, 886.

21. K. S. Lee, T. Kim, M. Shin, W. Lee, and J. Park, Anal. Chim. Acta, 1999, 380, 17.

22. Y. Kiba, Y. Otani, T. Yasukawa, and F. Mizutani, Electrochim. Acta, 2012, 81, 14.

23. American Diabetes Association: Diabetic nephropathy, Diabetes Care, 2003, 26, S94.

24. M. Parsons, D. J. Newman, M. Pugia, R. G. Newall, and C. P. Price, Clin. Nephrol., 1999, 51, 220.

25. R. E. Gilbert, A. Akdeniz, and G. Jerums, Diabetes Res. Clin. Pract., 1997, 35, 57.

26. O. Giampietro, G. Penno, A. Clerico, L. Cruschelli, A. Lucchetti, M. Nannipieri, M. Cecere, L. Rizzo, and R. Navalesi, Acta Diabetol., 1992, 28, 239.

27. G. F. Watts, J. E. Bennett, D. J. Rowe, R. W. Morris, W. Gatling, K. M. Shaw, and A. Polak, Clin. Chem., 1986, 32, 
1544.

28. K. Yoshimoto, E. Kaneko, and T. Yotsuyanagi, Chem. Lett., 2000, 29, 6 .

29. J. Isoe and E. Kaneko, Chem. Lett., 2006, 35, 922.

30. E. Kaneko, H. Yasuda, A. Higurashi, and H. Yoshimura, Analyst, 2010, 135, 1564.

31. C. P. Price, R. G. Newall, and J. C. Boyd, Clin. Chem., 2005, 51, 1577.

32. M. Guy, J. K. Borzomato, R. G. Newall, P. A. Kalra, and C. P. Price, Ann. Clin. Biochem., 2009, 46, 468.

33. D. J. Newman, M. J. Pugia, J. A. Lott, J. F. Wallace, and A.
M. Hiar, Clin. Chim. Acta, 2000, 294, 139.

34. S. S. Waikar, V. S. Sabbisetti, and J. V. Bonventre, Kidney Int., 2010, 78, 486.

35. J. A. Weber and A. P. Van Zenten, Clin. Chem., 1991, 37, 695.

36. I. Kubo, I. Karube, and S. Suzuki, Anal. Chim. Acta, 1983, 151,371 .

37. T. Tsuchida and K. Yoda, Clin. Chem., 1983, 29, 51.

38. E. J. Kim, T. Haruyama, Y. Yanagida, E. Kobatake, and M. Aizawa, Anal. Chim. Acta, 1999, 394, 225. 